\title{
Agonist and Antagonist Effects of ATP-Dependent Potassium Channel on Penicillin Induced Epilepsy in Rats
}

\author{
Sıçanlarda ATP-Bağımılı Potasyum Kanal Agonist ve Antagonistlerinin Penisilin ile \\ Olușturulmuș Epilepsi Üzerine Etkileri
}

\author{
Yıldız Acar'1, Recep Özmerdivenli'1, Șerif Demir', Ersin Beyazçiçek', Seyit Ankaralı', Özge Beyazçiçek', \\ Handan Ankaralı² \\ ${ }^{I}$ Düzce University School of Medicine, Department of Physiology, Düzce, Turkey; 2Düzce University School of Medicine, Department of \\ Biostatistics, Düzce, Turkey
}

\begin{abstract}
AIM: Epileptic seizures occur when the balance between stimulating and inhibiting systems in the brain tends to deterioration in the direction of stimulating systems dominancy. Antiepileptic effect of potassium $(K)$ channel openers has been shown in in vitro and in vivo studies. The purpose of this study is to investigate $K$ ATP channel agonist (pinacidil) and antagonists (glibenclamide) acute effects on experimental epilepsy models.
\end{abstract}

METHODS: In this study 32 adult male Wistar rats weighing 200$250 \mathrm{~g}$ were used, and these rats were divided into 4 groups as control (saline), glibenclamide, pinacidil and DMSO (dimethylsulfoxide). All rats were anesthetized with the dose of $1.25 \mathrm{~g} / \mathrm{kg}$ urethane, and it was administered to the rats intraperitoneally. After rats were anesthetized, the left part of the cortex was opened and the electrodes were placed on somatomotor area. Epileptiform activity was induced by intracortical (ic) administration of penicillin (500 IU, 2.5 $\mu l)$. At the 30th minutes of penicillin application, all substances (glibenclamide, pinacidil, DMSO, saline) was injected intraperitoneally (i.p). Obtained electrocorticographic (ECoG) data from recordings were analyzed by software. Spike-wave frequency and spike-wave amplitude of epileptiform activity were analyzed statistically.

RESULTS: Results of the study was showed that pinacidil decreases spike-wave frequency in epilepsy model which induced by penicillin $(p<0.05)$, however it does not have any significant effect on spike-wave amplitude of epileptiform activity ( $p>0.05$ ). Similarly, glibenclamide which is a blocker of KATP channel does not have any significant effect on both spike-wave frequency and spike-wave amplitude of epileptiform activity ( $p>0.05)$.

CONCLUSION: The results of the present study showed that administration of pinacidil has antiepileptic effect in penicillin induced epilepsy model in rats. Pinacidil may be a potential antiepileptogenic drug in future.

Key words: epilepsy; pinacidil; glibenclamide; KATP channels; penicillin

Doç. Dr. Recep Özmerdivenli, Düzce Üniversitesi Tip Fakültesi Fizyoloji Anabilim Dall, Kat: 281620 Düzce - Türkiye, Tel. 05324269898

Email.rozmerdivenli@hotmail.com

Geliş Taribi: 11.04.2015 • Kabul Tarihi: 09.06.2015

\section{ÖZET}

AMAÇ: Epileptik nöbetler, beyindeki uyarıcı ve duraklatıcı sistemler arasındaki dengenin, uyarıcı sistemlerin aktivitelerinin artıșı yönünde bozulması sonucunda meydana gelir. In vitro ve in vivo çalıșmalarında, birçok $K+$ kanal açıcılarının antiepileptik etkisi gösterilmiștir. Bu çalıșmada, çeșitli deneysel epilepsi modellerinde etkisi araștırlan KATP kanal agonist (pinacidil) ve antogonistlerinin (glibenclamide) penisilinle olușturulan deneysel epilepsi modeli üzerindeki akut etkisi araștırıldı.

YÖNTEM: Çalıșmada 200-250 gr ağırlığında 32 adet erkek WistarAlbino sıçan kullanıldı. Deney 10 hayvanları, kontrol, DMSO (dimetilsülfosit), pinasidil ve glibenklamid olarak dört gruba ayrıldı. Sıçanlar 1,25 gr/kg üretan dozunun intraperitoneal olarak uygulanmasıyla anestezi altına alındı. Sıçanlar anestezi altına alındıktan sonra sol korteks açıldı ve somatomotor alana elektrotlar yerleștirildi. Epileptiform aktivite intrakortikal (i.c.) penisilin (500 IU, 2,5 4 l) uygulanmasıyla olușturuldu. Penisilin uygulamasının 30. dakikasında tüm maddeler (salin, DMSO, pinasidil ve glibenklamid) intraperitoneal 15 (i.p.) olarak uygulandı. Kayıtlardan elde edilen elektrokortikografik (ECoG) veriler yazılım programı ile analiz edildi. Epileptiform aktivitenin diken dalga sıklığı ve diken dalga genliği istatistiksel olarak analiz edildi.

BULGULAR: Penisilin ile olușturulan deneysel epilepsi modelinde pinasidilin diken dalga sıkığını azalttığı $(p<0,05)$, fakat diken dalga genliği üzerinde anlamlı bir etkisinin olmadığı görüldü $(p>0,05)$. Benzer șekilde KATP kanal kapatıcısı olan glibenclamidenin ise hem diken dalga sıklığı hem diken dalga genliği üzerine anlamlı bir etkisinin olmadığını bulundu $(p>0,05)$.

SONUÇ: Yapılan çalıșmada pinasidil uygulamasının sıçanlarda penisilinle olușturulmuș deneysel epilepsi modeli üzerinde antiepileptik etkiye sahip olduğu gösterildi. Pinasidil gelecekte potansiyel bir antiepileptik ilaç olabilir.

Anahtar kelimeler: epilepsi; pinasidil; glibenklamid; KATP kanallarl; penisilin 


\section{Introduction}

There are 50 million patients around the world who suffer from epilepsy. Therefore, many significant studies are made for the prevention and treatment of epilepsy. The incidence of the epilepsy in children and elderly people are at the highest level, but its frequency in young people is at low level ${ }^{1}$.

Although the incidence of epilepsy is approximately $1 \%$ and it is one of the neurological disorders, many studies do not fully explain the cause of epilepsy in half of the patients ${ }^{2}$. Epileptic seizure is a clinical condition caused by excessive discharge of a group of neurons in the brain. This clinical situation contains sudden and temporary abnormal changes in level of consciousness, motor, sensory, autonomic or psychic. Epilepsy may occur without primarily damage or risk factor in the brain, and it may occur another underlying neurological, metabolic, toxic, or traumatic depending on secondary reasons $s^{3}$. Epileptic seizures may happen in many ways as loss of consciousness in which tonic, clonic muscle contraction or emotional and thought disorder ${ }^{4}$.

In epileptic seizures recorded during electrophysiological recordings both the abnormal discharge of spikes waves occur and it is quite significant changes in the frequency and amplitude of normal brain wave have been known for many years, and these changes are called epileptiform activity. However due to ethical and scientific rules the difficulty of studies on humans as in many fields of medical science, which requires the use of animal experiments in this regard. A substance should be tested in a variety of experimental models and effectiveness of this substance must be demonstrated before further researches and being a drug. For this purpose many epilepsy models have been developed ${ }^{5-8}$.

In recent studies, as an opinion that adenosine triphosphate-dependent potassium channels $\left(\mathrm{K}_{\text {ATP }}\right)$ to be effective on the formation process of epilepsy has prevailed. $\mathrm{K}_{\text {ATP }}$ channels are therapeutic targets, and both activators and inhibitors of $\mathrm{K}_{\mathrm{ATP}}$ channels used in clinics. Although secretion of insulin in pancreatic $\beta$-cell of $\mathrm{K}_{\text {ATP }}$ channels' classical role well understood, neuronal function is still unclear. In the study, which used dead mice, neuronal $\mathrm{K}_{\text {ATP }}$ channels are important to prevent the seizure induction and extension, and the numbers of active neuronal $\mathrm{K}_{\mathrm{ATP}}$ channels were found to be effective in controlling the seizure threshold .
Pinacidil, a $\mathrm{K}_{\text {ATP }}$ channel activator, effective on $\mathrm{K}_{\text {ATP }}$ channels in vascular smooth muscle and sarcolemma of cardiac muscle cells and mitochondria ${ }^{10}$. Genetic, molecular, physiological and pharmacological findings support that some $\mathrm{K}^{+}$channels have roles on the control of epileptogenesis and neuronal excitability. Therefore, there have been many studies on $\mathrm{K}^{+}$channel openers ${ }^{11,12}$. In the models of in vitro and in vivo, $\mathrm{K}^{+}$channel openers like diazoxide have been shown antiepileptic effects. Hence, this information suggests that $\mathrm{K}_{\text {ATP }}$ channel may be a potential target of novel drugs $^{13}$.

The purpose of this study is to investigate $\mathrm{K}_{\text {ATP }}$ channel agonist (pinacidil) and antagonist (glibenclamide) acute effects on penicillin induced epilepsy model by using electrocorticogram in anesthetized rats.

\section{Materials and Methods}

\section{Animals}

Male Wistar rats (200-250 g, aged of 12 weeks) were provided from the Duzce University, Experimental Animals Research Center (Duzce, Turkey) and housed in groups of six under the standard laboratory conditions. They were kept at constant room temperature $\left(21 \pm 2^{\circ} \mathrm{C}\right)$ under a $12 / 12 \mathrm{~h}$ light/dark cycle. Commercial food pellets and tap water were given freely available. The experiments were performed during the light portion of the cycle, between 08:00-12:00 a.m., to avoid circadian influences. All animal experiments were carried out in accordance with the regulations of the Ethics Committee of the Duzce University.

\section{Drugs and Doses}

As purchased chemicals, pinacidil (Sigma-Aldrich, St Louis, MO, USA) administered i.p. in $0.01 \mathrm{mg} / \mathrm{kg}$ and glibenclamide (Santa Cruz Biotechnology, Santa Cruz, CA) administered $1.0 \mathrm{mg} / \mathrm{kg}$ were used in the study. Pinacidil and glibenclamide were dissolved in dimethylsulfoxide (DMSO, Loba Chemie, India) following diluted with saline (99\% DMSO; $0.2 \mathrm{ml}$ final solution DMSO/saline 1:4, v/v, respectively). Urethane (Sigma-Aldrich, St Louis, MO, USA) in $1.25 \mathrm{~g} / \mathrm{kg}$ i.p. dose was used as anesthetic. Epileptic activity was stimulated by injecting $500 \mathrm{IU} / 2 \mu \mathrm{l}$ penicillin i.c. in $2 \mathrm{~mm}$ lateral, $1 \mathrm{~mm}$ anterior and $1.2 \mathrm{~mm}$ depth of Bregma line with Hamilton microenjector $(701 \mathrm{~N}$, Hamilton Co., Reno, NV, USA). All drugs were prepared daily. 


\section{Surgical Procedure}

Each of the animals in all groups, was anesthetized with urethane, and fixed onto stereotaxic frame (Harvard Instruments, South Natick, MA, USA). After shaving the head area, the scalp was incised through midline, from front to back with scalpel. Then, the bone part above the left cerebral cortex was slenderized with tour motor (Proxxon Minimot 40/E), and carefully removed.

\section{Experimental Groups}

Group 1, "control group", which injected penicillin + saline (500 IU $/ 2 \mu l$, i.c.), $[\mathrm{n}=8]$.

Group 2, "DMSO (solvent) group", which injected penicillin + DMSO (1 ml/kg i.p.), $[\mathrm{n}=8]$.

Group 3, "0.01 mg/kg pinacidil group”, which injected penicillin + pinacidil, $[\mathrm{n}=8]$.

Group 4, "1.0 mg $/ \mathrm{kg}$ glibenclamide group", which injected penicillin + glibenclamide, $[\mathrm{n}=8]$.

\section{Electrophysiological Records}

Two Ag-AgCl top electrodes were placed on the somatomotor cortex area, which was opened on left hemisphere in the lateral of Bregma line. After the electrodes were placed, electrocortigography $(\mathrm{ECoG})$ records (PowerLab/8SP, AD Instruments Pty Ltd, Castle Hill, NSW, and Australia) were taken throughout the experiment. Before application of penicillin, five minutes basal activity recording was taken. Thereafter epileptiform activity was induced by intracortical administration of penicillin. At the 30th minutes of penicillin application, substances (saline, DMSO, pinacidil and glibenclamide) were injected. The analyses of the obtained records were performed with the Power Lab Chart v.6.0 software package. The epileptiform activity, which was occurring in bipolar spike and spike-wave complexes, were examined. Additionally, the values of spike wave frequency and amplitudes per 5 minuteperiods of ECoG recordings of each animal were measured and used as data.

\section{Statistical Analysis}

Spike wave frequency and amplitude of epileptiform activities data were digitized and computed from the records of each animal by using Chart software. In the evaluation of received data, each group changes from baseline in their various periods were evaluated by paired $t$-test, the difference between the four groups in terms of periodic changes were evaluated with oneway analysis of variance, and the significant differences were evaluated with Tukey post hoc test, $\mathrm{p}<0.05$ was considered as significant. PASW 18.0 software was used for statistical calculations. The resulting data descriptor values \pm standard deviation (SD) were presented in graphs.

\section{Results}

Basal ECoG activity of each rats were recorded before the administration of substances. Spontaneous spike was not detected in any animals. Epileptiform activities that characterized with bilateral spikes began within 3-8 min after penicillin application and lasted for 3-4 h. Frequency and amplitude of spikes reached a constant level about $30 \mathrm{~min}$ after penicillin application. Including from five minutes before the injection of pinacidil and glibenclamide 125 minutes was divided into 5 minutes periods. Consequently, 25 different measurements values were obtained.

\section{The Effect of Pinacidil and Glibenclamide on Spike- Wave Frequency of Epileptiform Activity}

After penicillin injection, the mean of spike wave frequency of epileptiform activity was between 136.38 spike/ $\mathrm{min}$ and $82.00 \mathrm{spike} / \mathrm{min}$ in the control group. Decreasing in the frequency of epileptiform activity continued for 125 minutes (except for some periods) (Fig. 1, Table 1). The mean of spike wave frequency of epileptiform activity in DMSO group was between $134.38 \mathrm{spike} / \mathrm{min}$ and $64.38 \mathrm{spike} / \mathrm{min}$ after DMSO injection and there was no statistically significant difference according to the control group ( $p>0.05)$ (Fig. 1, Table 1).

The mean of spike wave frequency of epileptiform activity of $1.0 \mathrm{mg} / \mathrm{kg}$ glibenclamide group was between $56.00 \mathrm{spike} / \mathrm{min}$ and $127.00 \mathrm{spike} / \mathrm{min}$ after injection and there was no statistically significant difference comparing to the control group ( $p>0.05)$ (Fig. 1, Table 1).

After $0.01 \mathrm{mg} / \mathrm{kg}$ pinacidil injection, spike wave frequency of epileptiform activity mean was between $4.38 \mathrm{spike} / \mathrm{min}$ and $106 \mathrm{spike} / \mathrm{min}$ in the pinacidil group. After the injection of pinacidil at $0.01 \mathrm{mg} / \mathrm{kg}$ dose reduced the mean spike wave frequency in the time periods of $1-5,11-55,61-65,76-80$ and $81-85$, but these decreasing were not statistically significant when it is compared with the other groups $(p>0.05)$ (Table 1). However, decreasing effects of $0.01 \mathrm{mg} / \mathrm{kg}$ 


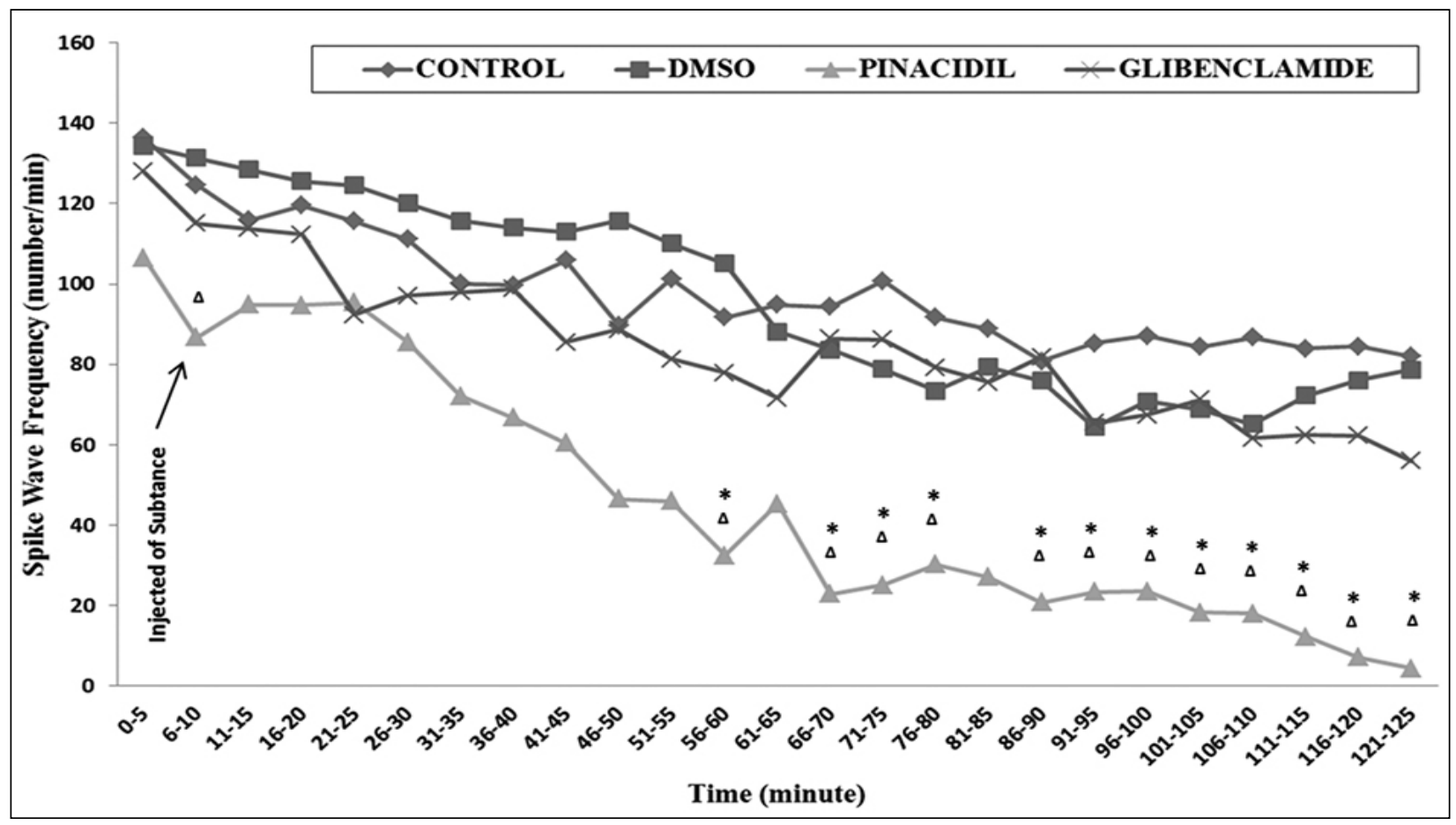

Figure 1. Mean values of spike-wave frequency (number/min) obtained from recording after penicillin. (*: Significance compared to control group [p<0,05]; $\Delta$ : Significance compared to DMSO group).

Table 1. The effects of control, DMSO, pinacidil and glibenclamide on frequency of penicillin-induced epileptiform activity

\begin{tabular}{|c|c|c|c|c|c|c|c|c|c|c|}
\hline \multirow{2}{*}{$\begin{array}{l}\text { Time } \\
\text { (min) }\end{array}$} & \multirow[b]{2}{*}{$\mathrm{N}$} & \multicolumn{2}{|c|}{ Control } & \multicolumn{2}{|c|}{ DMSO } & \multicolumn{2}{|c|}{ Pinacidil } & \multicolumn{2}{|c|}{ Glibenclamide } & \multirow[b]{2}{*}{$P$} \\
\hline & & Mean \pm SEM & Median & Mean \pm SEM & Median & Mean \pm SEM & Median & Mean \pm SEM & Median & \\
\hline $1-5$ & 8 & $136,38 \pm 54,047$ & 121,50 & $134,38 \pm 30,085$ & 133,00 & $106,50 \pm 34,013$ & 98,00 & $127,88 \pm 38,27$ & 110,50 & 0,473 \\
\hline $6-10$ & 8 & $124,63 \pm 35,290$ & 119,50 & $131,38 \pm 25,427$ & 130,00 & $86,75 \pm 27,732^{\Delta}$ & 90,50 & $115,00 \pm 48,59$ & 105,50 & 0,048 \\
\hline $11-15$ & 8 & $115,88 \pm 41,495$ & 111,00 & $128,50 \pm 32,628$ & 128,50 & $94,88 \pm 17,291$ & 100,00 & $113,75 \pm 62,47$ & 107,00 & 0,272 \\
\hline $16-20$ & 8 & $119,50 \pm 25,518$ & 119,50 & $125,50 \pm 36,095$ & 121,00 & $94,75 \pm 19,631$ & 97,50 & $112,25 \pm 59,17$ & 135,00 & 0,224 \\
\hline 21-25 & 8 & $115,63 \pm 24,477$ & 107,50 & $124,50 \pm 40,118$ & 119,00 & $95,38 \pm 30,194$ & 105,00 & $92,38 \pm 57,56$ & 98,50 & 0,478 \\
\hline $26-30$ & 8 & $111,13 \pm 22,643$ & 106,00 & $120,00 \pm 37,401$ & 110,00 & $85,50 \pm 32,036$ & 95,50 & $97,13 \pm 65,53$ & 110,50 & 0,568 \\
\hline 31-35 & 8 & $100,13 \pm 29,464$ & 100,50 & $115,75 \pm 40,461$ & 99,50 & $72,13 \pm 43,943$ & 68,50 & $98,00 \pm 53,65$ & 101,50 & 0,507 \\
\hline $36-40$ & 8 & $99,63 \pm 26,295$ & 93,00 & $114,00 \pm 36,426$ & 102,50 & $66,75 \pm 57,708$ & 68,00 & $98,75 \pm 57,87$ & 97,50 & 0,497 \\
\hline 41-45 & 8 & $105,88 \pm 30,694$ & 98,50 & $113,00 \pm 43,612$ & 95,50 & $60,50 \pm 55,379$ & 61,50 & $85,50 \pm 50,87$ & 81,50 & 0,267 \\
\hline $46-50$ & 8 & $89,75 \pm 24,064$ & 85,50 & $115,75 \pm 49,352$ & 95,50 & $46,50 \pm 46,347$ & 38,50 & $88,63 \pm 54,59$ & 90,50 & 0,116 \\
\hline $51-55$ & 8 & $101,25 \pm 38,340$ & 87,00 & $110,13 \pm 47,221$ & 85,00 & $46,00 \pm 41,463$ & 50,50 & $81,38 \pm 52,89$ & 78,50 & 0,090 \\
\hline $56-60$ & 8 & $91,75 \pm 30,775$ & 90,00 & $105,13 \pm 38,765$ & 83,00 & $32,50 \pm 33,037^{\star \Delta}$ & 25,50 & $77,88 \pm 55,31$ & 77,50 & 0,004 \\
\hline $61-65$ & 8 & $94,88 \pm 33,336$ & 85,50 & $88,13 \pm 13,442$ & 86,00 & $45,38 \pm 52,877$ & 29,50 & $71,63 \pm 55,47$ & 76,00 & 0,200 \\
\hline $66-70$ & 8 & $94,25 \pm 40,372$ & 79,50 & $83,63 \pm 35,018$ & 78,50 & $22,88 \pm 29,897^{\star \Delta}$ & 4,00 & $86,38 \pm 90,79$ & 70,00 & 0,009 \\
\hline 71-75 & 8 & $100,75 \pm 44,506$ & 80,00 & $78,88 \pm 27,772$ & 78,00 & $25,13 \pm 31,133^{*} \Delta$ & 7,50 & $86,13 \pm 92,96$ & 72,00 & 0,010 \\
\hline $76-80$ & 8 & $91,63 \pm 50,560$ & 74,00 & $73,50 \pm 25,840$ & 80,00 & $30,25 \pm 41,018$ & 1,50 & $79,25 \pm 90,45$ & 65,00 & 0,161 \\
\hline $81-85$ & 8 & $88,75 \pm 38,291$ & 79,00 & $79,38 \pm 14,937$ & 80,00 & $27,13 \pm 37,104$ & 1,50 & $75,50 \pm 82,45$ & 69,00 & 0,067 \\
\hline $86-90$ & 8 & $80,75^{\mathrm{a}} \pm 38,243$ & 72,00 & $75,88^{a} \pm 12,552$ & 77,50 & $20,75^{\mathrm{b}} \pm 30,886^{\star} \Delta$ & 1,50 & $81,88^{a} \pm 86,37$ & 73,00 & 0,035 \\
\hline 91-95 & 8 & $85,25 \pm 32,208$ & 82,00 & $64,38 \pm 23,250$ & 70,00 & $23,38 \pm 34,924^{*} \Delta$ & 0,50 & $65,38 \pm 70,51$ & 58,50 & 0,032 \\
\hline 96-100 & 8 & $87,13 \pm 36,385$ & 77,50 & $70,88 \pm 26,205$ & 78,00 & $23,50 \pm 35,881^{\star \Delta}$ & 2,00 & $67,38 \pm 70,41$ & 63,00 & 0,031 \\
\hline 101-105 & 8 & $84,38 \pm 40,659$ & 72,00 & $68,88 \pm 22,731$ & 75,50 & $18,25 \pm 34,204^{\star \Delta}$ & 0,00 & $71,25 \pm 69,42$ & 70,50 & 0,036 \\
\hline $106-110$ & 8 & $86,75 \pm 36,507$ & 86,00 & $65,13 \pm 14,377$ & 65,50 & $18,00 \pm 27,198^{\star \Delta}$ & 2,50 & $61,63 \pm 66,09$ & 54,00 & 0,009 \\
\hline 111-115 & 8 & $84,00 \pm 48,146$ & 83,00 & $72,25 \pm 16,140$ & 70,50 & $12,25 \pm 22,657^{\star \Delta}$ & 1,00 & $62,38 \pm 65,95$ & 56,50 & 0,012 \\
\hline $116-120$ & 8 & $84,50 \pm 35,984$ & 81,00 & $76,13 \pm 19,172$ & 73,50 & $7,13 \pm 18,954^{\star \Delta}$ & 0,00 & $62,25 \pm 62,96$ & 49,50 & 0,004 \\
\hline $121-125$ & 8 & $82,00 \pm 40,178$ & 88,50 & $78,75 \pm 20,408$ & 76,00 & $4,38 \pm 11,173^{\star \Delta}$ & 0,50 & $56,00 \pm 59,14$ & 38,50 & 0,003 \\
\hline
\end{tabular}


dose pinacidil in the spike wave frequencies were statistically significant in the time periods of 56-60, 66-70, $71-75$ and 86-125. The mean spike-wave frequency of $0.01 \mathrm{mg} / \mathrm{kg}$ dose pinacidil group were observed to be significantly lower comparing to the control and DMSO groups in most of periods $(\mathrm{p}<0.05)$ (Table 1$)$. Moreover administration of $0.01 \mathrm{mg} / \mathrm{kg}$ dose pinacidil decreased spike-wave frequency as compared with other group which was DMSO group in 6-10 time period $(\mathrm{p}=0.048)$ (Fig. 1, Table 1).

\section{The Effect of Pinacidil and Glibenclamide on Spike- Wave Amplitude of Epileptiform Activity}

Considering the data obtained from the control group, the mean spike wave amplitude of epileptiform activity reached a maximum value $(3,444 \mathrm{mV})$ at $21-25$ time period after penicillin and gradually decreasing continued for $125 \mathrm{~min}$ (Fig. 2). In DMSO group the mean spike wave amplitude of epileptiform activity were between 3,915 $\mathrm{mV}$ (46-50 $\mathrm{min}$ ) and $2.462 \mathrm{mV}(121-$ $125 \mathrm{~min}$ ) (Fig. 2, Table 2). At the same time, effect of DMSO on epileptiform activity was investigated. Although, DMSO administration increased the spikewave amplitude as compared with the control group, there was no statistically significance ( $p>0.05)$ (Fig. 2).

There was no significant difference in the spike-wave amplitude of epileptiform activity of $0.01 \mathrm{mg} / \mathrm{kg}$ pinacidil group compared to the other groups in all time periods ( $>0.05)$ (Fig. 2, Table 2). There was no significant difference in the spike-wave amplitude of epileptiform activity of $1.00 \mathrm{mg} / \mathrm{kg}$ glibenclamide group compared to the other groups in all time periods $(\mathrm{p}>0.05)$.

\section{Discussion}

In the present study, administered intraperitoneally in the doses of $0.01 \mathrm{mg} / \mathrm{kg}$ pinacidil and $1.0 \mathrm{mg} / \mathrm{kg}$ glibenclamide effects on epileptiform activity in rats which induced by penicillin have been researched. When epileptiform activity spike-wave frequency mean value analyzed which belongs to pinacidil 0.01 $\mathrm{mg} / \mathrm{kg}$ dose in the records, except for some period, was determined that in the 125 minutes time interval 0.01 $\mathrm{mg} / \mathrm{kg}$ dose pinacidil is significantly lower compared to the control and DMSO group. Thus, pinacidil decreased the frequency of epileptiform activity and this effect lasted for at least 2 hours after penicillin injection was observed. This finding is important due to pinacidil effects on epilepsy did not previously studied electrophysiologically. However, effect of pinacidil on the epileptiform activity spike-wave amplitude was not observed. Similarly, glibenclamide, which is a selective and strong blocker on $\mathrm{K}_{\text {ATP }}$ channels, intraperitoneal administration in the dose of $1.0 \mathrm{mg} / \mathrm{kg}$ has no effect on epileptic discharges in experimental epilepsy model which induced by penicillin.

An epileptic seizure occurs when the balance between stimulating and inhibiting systems in the brain tends to deterioration in the direction of stimulating systems dominancy ${ }^{14}$. Nowadays, there have been many studies on both causes and treatment of epilepsy ${ }^{15-17}$. Several experimental models have been used for explanation of mechanisms underlying epilepsy, testing of new antiepileptic, the development of appropriate diagnostic approaches and treatment modalities or determination of new approaches in order to eliminate the problems caused by epilepsy. In recent studies have been dominated by the view that the ATP-dependent potassium channel effective on the formation process of epilepsy. Many proconvulsant and anticonvulsant agents have been studied in experimental epilepsy models. We conducted our study by using pinacidil, which is an ATP-dependent potassium channel agonist, and glibenclamide, which is an ATP-dependent potassium channel antagonist.

$\mathrm{K}_{\text {ATP }}$ channel openers such as diazoxide in appropriate concentration, which used in the treatment of hypertension in accordance with the clinical purpose, or $\mathrm{K}_{\mathrm{ATP}}$ channel blockers like sulfonylureas, which used in the treatment of type II diabetes may be effective on control of ischemic tolerance and seizure threshold are considered ${ }^{18}$. In a conducted study showed that subunit of $\mathrm{K}_{\text {ATP }}$ channels in substantia nigra pars reticulata $(\mathrm{SNr})$ has special effect on the formation of epilepsy ${ }^{19}$. Obtained results from studies on transgenic rats support that $\mathrm{K}_{\text {ATP }}$ channels has role in the spread of seizures. Made with ATP-sensitive $\mathrm{K}^{+}$channel openers like diazoxide and cromakalim in vivo and in vitro experiments antiepileptic effects of these substances are shown ${ }^{13,20}$. Similar results were obtained from some performed studies ${ }^{21,22}$.

Potassium channel openers, as a result of membrane hyperpolarization, reduce neuronal excitability. Moreover, potassium channel openers have an antinociceptive effect mediated by the activation of endorphins, free encephalin and opioid receptors. There are studies on pinacidil and cromakalim both have been shown analgesic effect via nitric oxide, which is affected by the opening of sarcolemmal $\mathrm{K}_{\text {ATP }}$ channels ${ }^{25-27}$. 


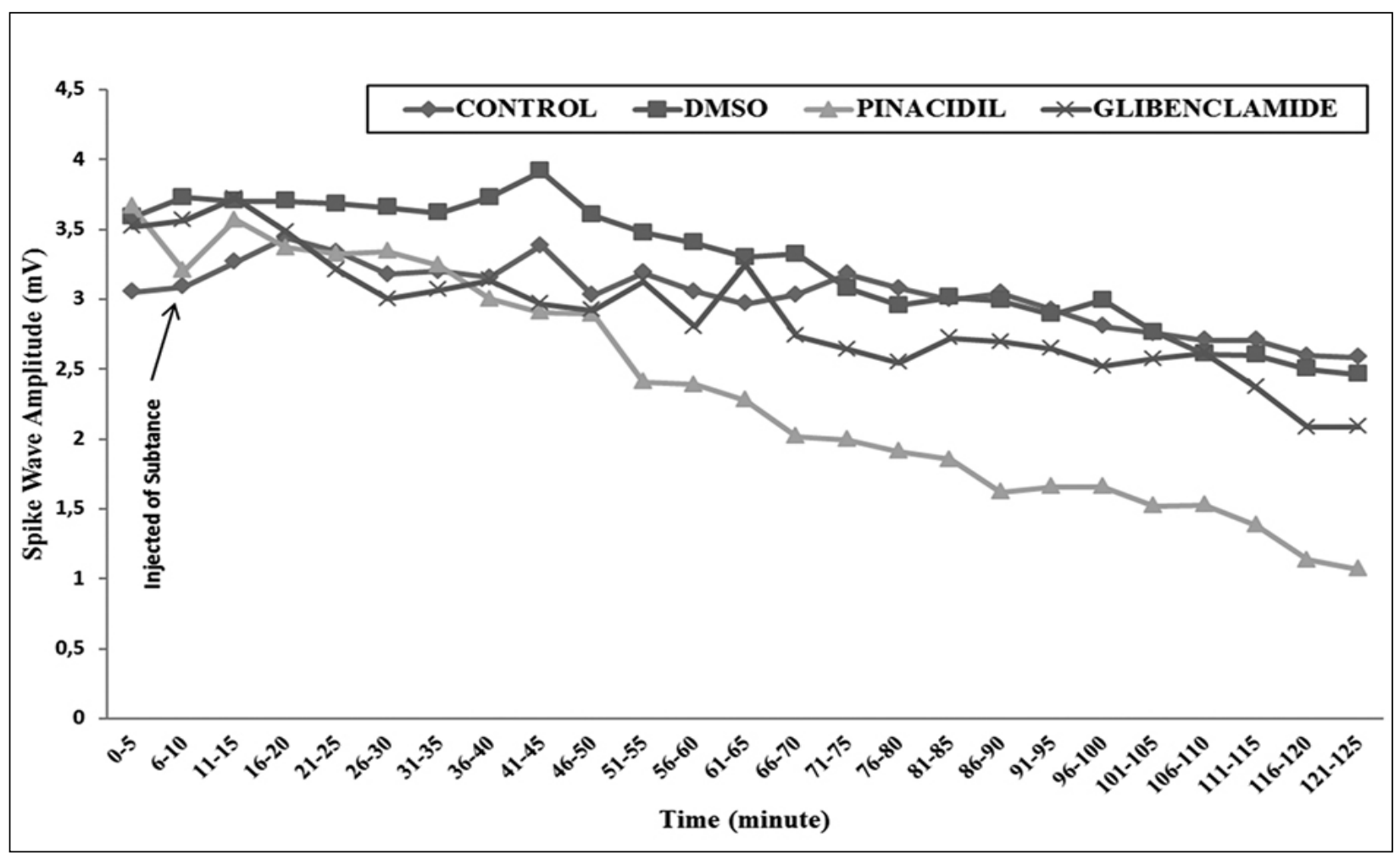

Figure 2. Spike-wave amplitude (mV) mean values obtained from recording after penicillin.

Table 2. The effects of control, DMSO, pinacidil and glibenclamide on amplitude of penicillin-induced epileptiform activity

\begin{tabular}{|c|c|c|c|c|c|c|c|c|c|c|}
\hline \multirow{2}{*}{$\begin{array}{l}\text { Time } \\
\text { (min) }\end{array}$} & \multicolumn{3}{|c|}{ Control } & \multicolumn{2}{|c|}{ DMSO } & \multicolumn{2}{|c|}{ Pinacidil } & \multicolumn{2}{|c|}{ Glibenclamide } & \multirow[b]{2}{*}{$P$} \\
\hline & $\mathrm{N}$ & Mean \pm SEM & Median & Mean \pm SEM & Median & Mean \pm SEM & Median & Mean \pm SEM & Median & \\
\hline $1-5$ & 8 & $3,050 \pm 1,197$ & 3,294 & $3,587 \pm 1,200$ & 3,674 & $3,666 \pm 1,486$ & 4,030 & $3,518 \pm 1,08$ & 3,778 & 0,421 \\
\hline $6-10$ & 8 & $3,090 \pm 1,176$ & 3,306 & $3,731 \pm 1,246$ & 3,798 & $3,207 \pm 2,057$ & 3,127 & $3,566 \pm 1,057$ & 4,004 & 0,948 \\
\hline $11-15$ & 8 & $3,268 \pm 1,330$ & 3,350 & $3,703 \pm 1,271$ & 3,841 & $3,568 \pm 1,667$ & 3,108 & $3,723 \pm 1,304$ & 3,977 & 0,474 \\
\hline $16-20$ & 8 & $3,444 \pm 1,426$ & 3,355 & $3,702 \pm 1,247$ & 3,945 & $3,369 \pm 1,639$ & 2,677 & $3,486 \pm 1,158$ & 3,915 & 0,995 \\
\hline $21-25$ & 8 & $3,340 \pm 1,192$ & 3,400 & $3,682 \pm 1,218$ & 3,725 & $3,323 \pm 1,649$ & 2,806 & $3,208 \pm 1,315$ & 3,328 & 0,416 \\
\hline $26-30$ & 8 & $3,179 \pm 1,010$ & 3,388 & $3,657 \pm 1,128$ & 3,744 & $3,341 \pm 1,588$ & 3,406 & $3,004 \pm 1,116$ & 3,071 & 0,970 \\
\hline $31-35$ & 8 & $3,200 \pm 0,975$ & 3,345 & $3,617 \pm 1,111$ & 3,668 & $3,244 \pm 1,628$ & 3,379 & $3,069 \pm 1,478$ & 2,728 & 0,958 \\
\hline $36-40$ & 8 & $3,157 \pm 1,019$ & 3,398 & $3,729 \pm 1,089$ & 3,680 & $3,001 \pm 1,843$ & 3,110 & $3,137 \pm 1,588$ & 2,350 & 0,502 \\
\hline $41-45$ & 8 & $3,384 \pm 0,625$ & 3,376 & $3,915 \pm 0,655$ & 3,719 & $2,905 \pm 1,714$ & 3,106 & $2,970 \pm 1,532$ & 2,332 & 0,361 \\
\hline $46-50$ & 8 & $3,028 \pm 0,800$ & 3,308 & $3,602 \pm 0,891$ & 3,562 & $2,894 \pm 1,488$ & 2,853 & $2,922 \pm 1,494$ & 2,328 & 0,870 \\
\hline $51-55$ & 8 & $3,192 \pm 0,980$ & 3,566 & $3,477 \pm 1,000$ & 3,408 & $2,411 \pm 1,521$ & 2,489 & $3,129 \pm 1,749$ & 3,017 & 0,672 \\
\hline $56-60$ & 8 & $3,057 \pm 0,745$ & 3,308 & $3,403 \pm 0,862$ & 3,290 & $2,389 \pm 1,417$ & 2,367 & $2,802 \pm 1,593$ & 2,258 & 0,504 \\
\hline $61-65$ & 8 & $2,970 \pm 0,778$ & 3,139 & $3,300 \pm 1,056$ & 3,132 & $2,280 \pm 1,541$ & 2,379 & $3,247 \pm 1,842$ & 3,171 & 0,222 \\
\hline $66-70$ & 8 & $3,032 \pm 0,933$ & 3,447 & $3,323 \pm 1,126$ & 3,161 & $2,019 \pm 1,417$ & 2,105 & $2,740 \pm 1,446$ & 2,253 & 0,695 \\
\hline 71-75 & 8 & $3,183 \pm 0,914$ & 3,558 & $3,080 \pm 1,038$ & 3,098 & $1,995 \pm 1,300$ & 2,162 & $2,642 \pm 1,429$ & 2,283 & 0,505 \\
\hline $76-80$ & 8 & $3,080 \pm 0,871$ & 3,423 & $2,956 \pm 1,015$ & 2,960 & $1,914 \pm 1,352$ & 1,932 & $2,548 \pm 1,434$ & 2,155 & 0,658 \\
\hline $81-85$ & 8 & $3,000 \pm 0,718$ & 3,256 & $3,013 \pm 1,016$ & 2,916 & $1,853 \pm 1,221$ & 1,832 & $2,725 \pm 1,513$ & 2,968 & 0,158 \\
\hline $86-90$ & 8 & $3,045 \pm 0,832$ & 3,281 & $2,993 \pm 1,048$ & 2,860 & $1,619 \pm 0,958$ & 1,448 & $2,696 \pm 1,460$ & 2,751 & 0,579 \\
\hline 91-95 & 8 & $2,926 \pm 0,796$ & 3,049 & $2,892 \pm 1,081$ & 2,668 & $1,661 \pm 1,034$ & 1,744 & $2,647 \pm 1,550$ & 2,683 & 0,625 \\
\hline $96-100$ & 8 & $2,806 \pm 0,763$ & 2,775 & $2,995 \pm 1,095$ & 2,904 & $1,661 \pm 1,027$ & 1,754 & $2,520 \pm 1,409$ & 2,663 & 0,742 \\
\hline 101-105 & 8 & $2,756 \pm 0,739$ & 2,754 & $2,766 \pm 0,984$ & 2,637 & $1,520 \pm 0,953$ & 1,409 & $2,574 \pm 1,549$ & 2,530 & 0,362 \\
\hline $106-110$ & 8 & $2,706 \pm 0,870$ & 2,701 & $2,609 \pm 0,891$ & 2,537 & $1,529 \pm 0,890$ & 1,602 & $2,616 \pm 1,821$ & 2,320 & 0,899 \\
\hline 111-115 & 8 & $2,709 \pm 0,855$ & 2,699 & $2,600 \pm 1,040$ & 2,494 & $1,382 \pm 0,678$ & 1,586 & $2,370 \pm 1,502$ & 2,230 & 0,918 \\
\hline $116-120$ & 8 & $2,597 \pm 0,844$ & 2,686 & $2,501 \pm 0,924$ & 2,411 & $1,136 \pm 0,472$ & 1,182 & $2,083 \pm 1,390$ & 1,939 & 0,775 \\
\hline 121-125 & 8 & $2,585 \pm 0,907$ & 2,671 & $2,462 \pm 1,004$ & 2,350 & $1,069 \pm 0,460$ & ,989 & $2,089 \pm 1,610$ & 1,947 & 0,258 \\
\hline
\end{tabular}


Shafaroodi-et al (2007), investigated using the specific $\mathrm{K}_{\text {ATP }}$ channel blocker glibenclamide, the specific $\mathrm{K}_{\text {ATP }}$ channel opener cromakalim, and the possible involvement of $\mathrm{K}_{\text {ATP }}$ channels in the effects of morphine on pentylenetetrazole (PTZ)-induced seizure threshold in mice. $\mathrm{K}_{\mathrm{ATP}}$ channel blockade depolarizes neurons. $\mathrm{K}_{\text {ATP }}$ channels have regulatory effects in the formation of epileptic seizures induced by PTZ. Their data indicated that the non-effective dose of glibenclamide was able to antagonize the proconvulsant effects of morphine and this effect of glibenclamide was inhibited by co-administration of cromakalim ${ }^{26}$. Pharmacological studies support that $\mathrm{K}_{\text {ATP }}$ channels have important role on control of seizure threshold ${ }^{27}$.

Almost everything that interferes the normal functioning of nerve cells in the brain can cause epilepsy. Head traumas, genetic factors, infection and congenital disorders are among those reasons. The treatment of epilepsy is based on control seizures with drugs. Complete recovery is possible in some types of epilepsy (primary type). Spontaneous-abnormal electrical discharges during epileptic seizures cause to increase $\mathrm{K}^{+}$ions in intracellular area. Inducing of seizure by penicillin, which applied directly to the cerebral cortex, is occurred by blocking of inhibitory postsynaptic potential (IPSP). Reduction of inhibition in a cortical region has a very important effect on the behavior of neuron groups. Therefore, the administration of the convulsant drug may cause an acute focal epilepsy without causing morphological changes in cells ${ }^{20,28}$. Sullivan and Osorio (1991) induced epileptiform activity with administered penicillin intraperitoneally in rats ${ }^{29}$. Walden et al (1992) applied local penicillin to cortex surface, and they reported that epileptiform potentials seen in ECoG recordings after $4-5$ minutes administration of penicillin ${ }^{30}$. In recent study, epileptiform activities began within 3-8 minutes after penicillin application and lasted for 3-4 hours.

In conclusion, in this study showed that acute using of $0.01 \mathrm{mg} / \mathrm{kg}$ pinacidil decreases the spike-wave frequency of epileptiform activity. We did not perform molecular and biochemical analyses in this study, but only investigated the effect on epileptiform activity electrophysiologically. Conducting multidisciplinary studies involving biochemical and histological studies, about this issue will help to enlighten this matter. In epilepsy treatment for understanding the $\mathrm{K}_{\text {ATP }}$ channel agonist efficacy and mechanism of action must be made many basic and clinical researches.

\section{Acknowledgements}

This study was supported by the Committee for Scientific Research of Düzce University with the code of 2012.04.HD.076.

\section{Conflicts of Interest}

The authors have indicated that they have no conflicts of interest regarding the content of this article.

\section{References}

1. Zupec-Kania BA, Spellman E. An overview of the ketogenic diet for pediatric epilepsy. Nutr Clin Pract 2008;23:589-96.

2. Henriksen G, Willoch F. Imaging of opioid receptors in the central nervous system. Brain 2008;131:1171-96.

3. Evlice A, Demir T, Aslan K, et al. Disability at Neurological Diseases. Cukurova Medical Journal 2014;39:566-71.

4. Shneker BF, Fountain NB. Antiepileptic drug selection for partial-onset seizures. Curr Treat Options Neurol 2012;14:35668.

5. Kalkan E, Akhan G, Koyuncuoğlu HR, et al. Tavşanlarda kristalize penisilin ile oluşturulmuş bir deneysel epilepsi modeli. S. D. Ü. Tip Fak. Derg 1996;3:5-8.

6. Bağırıcı F, Gökçe FM, Marangoz C. Sıçanlarda penisilinle oluşturulan deneysel epilepsiye nikardipinin etkisi. Çukurova Üniversitesi Tip Fakültesi Dergisi 1999;24:83-9.

7. Koyu A, Akhan G, Koyuncuoğlu HR. Tavşanlarda topikal penisilin uygulaması ile oluşturulan deneysel epilepsi sonucu beyin eser element değişiklikleri. S. D. Ü. Tip Fak. Derg. 2004;11:10-3.

8. Bambal G, Çakıl D, Ekici F. Models of experimental epilepsy. Journal of Clinical and Experimental Investigations 2011;2:118-23.

9. Yamada K. Glucose metabolism in the basal ganglia. Brain Nerve 2009;61:381-8.

10. Liss B, Roeper J. A role for neuronal K (ATP) channels in metabolic control of the seizure gate. Trends Pharmacol Sci 2001;22:599-601.

11. Lillis KP, Dulla C, Maheshwari A, et al. WONOEP appraisal: Molecular and cellular imaging in epilepsy. Epilepsia 2015;1-9.

12. Singh P, Gupta S, Sharma B. Melatonin receptor and KATP channel modulation in experimental vascular dementia. Physiol Behav 2015;142:66-78.

13. Nielsen PE, Krogsgaard A, McNair A, et al. Treatment of acute, severe hypertension assessed in a multicentre study. The effects of rest and furosemide and a randomized clinical trial of chlorpromazine, dihydralazine and diazoxide. Ugeskr Laeger 1981;143:1451-7.

14. Marson A, Jacoby A, Johnson A, et al. Medical Researh Council MESS Study Group. Immediate versus deferred antiepileptic drug treatment for early epilepsy and single seizures. A randomized controlled trial. Lancet 2005;365:2007-13. 
15. Herranz JL, Argumosa A. Characteristics of drugs used in the treatment of acute convulsions and convulsive status. Rev Neurol 2000;31:757-62.

16. Kalviainen R. Aikia M. Saukkonen AM, et al. Vigabatrin vs Carbamazepine monotherap in patients with newly diagnoset epilepsy: a randomized controlled study. Arch Neurol 1995;52:989-96.

17. Jazayeri A, Zolfaghari S, Ostadhadi S. Anticonvulsant effect of diazoxide against dichlorvos-induced seizures in mice. Scientific World Journal 2013;2013.

18. Bonfanti DH, Alcazar LP, Arakaki PA, et al. ATP-dependent potassium channels and type 2 diabetes mellitus. Clin Biochem 2015.

19. Ji JJ, Chen L, Duan X, et al. BK channels reveal novel phosphate sensitivity in SNr neurons. PLoS One 2012;7: e52148.

20. Jimenez-Jimenez D, Abete-Rivas M, Martin-López D, et al. Incidence of functional bi-temporal connections in the human brain in vivo and their relevance to epilepsy surgery. Cortex 2015;65:208-18.

21. Donato F, Filho CB, Giacomeli R, et al. Evidence for the Involvement of Potassium Channel Inhibition in the Antidepressant-Like Effects of Hesperidin in the Tail Suspension Test in Mice. J Med Food 2015.

22. Sarantopoulos C, McCallum B, Sapunar D, et al. ATPsensitive potassium channels in rat primary afferent neurons: the effect of neuropathic injury and gabapentin. Neurosci Lett 2003;343:185-9.
23. Ponnoth DS, Nayeem MA, Tilley SL, et al. CYP-epoxygenases contribute to $\mathrm{A} 2 \mathrm{~A}$ receptor-mediated aortic relaxation via sarcolemmal KATP channels. Am J Physiol Regul Integr Comp Physiol 2012;303: R1003-R1010.

24. Lee JY, Ko EJ, Ahn KD, et al. The role of $\mathrm{K}+$ conductances in regulating membrane excitability in human gastric corpus smooth muscle. Am J Physiol Gastrointest Liver Physiol 2015 Jan 15: ajpgi 002202014.

25. Wickenden AD. Potassium channels as anti-epileptic drug targets. Neuropharmacology 2002;43:1055-60.

26. Shafaroodi H, Asadi S, Sadeghipour H, et al. Role of ATPsensitive potassium channels in the biphasic effects of morphine on pentylenetetrazole-inducedseizure threshold in mice. Epilepsy Res 2007;75:63-9.

27. Wickenden AD. Potassium channels as anti-epileptic drug targets. Neuropharmacology 2002;43:1055-60.

28. Iffland $\mathrm{PH}$, Carvalho-Tavares J, Trigunaite A, et al. Intracellular and circulating neuronal antinuclear antibodies in human epilepsy. Neurobiol Dis 2013;59:206-19.

29. Sullivan HC, Osorio I. Aggravation of penicillin-induced epilepsy in rats with locus ceruleus lesions. Epilepsia 1991;32:591-6.

30. Walden J, Straub H, Speckmann EJ. Epileptogenesis: Contributions of calcium ions and antiepileptic calcium antagonists. Acta Neurol Scand 1992;86:41-6. 